\title{
DAMPAK PENGGUNAAN GADGET TERHADAP PRILAKU SOSIAL ANAK PESANTREN RAMADHAN DI KELURAHAN BANUARAN NAN XX
}

\author{
YOHANIS \\ STISIP Imam Bonjol \\ yohanis191@gmail.com
}

\begin{abstract}
This study aims to examine the phenomenon of the use of gadgets and their impact on the social behavior of Islamic boarding school children in the Banuaran Nan XX Village. The type of research is qualitative research with descriptive method. The selection of informants was done by using purposive sampling technique. The types of data are primary data and secondary data collected through observation, interviews and documentation studies. The results showed that most of the students used gadgets. The features that are often used are camera, WA, Game, Mp3, YouTube, internet and social media. These features are used to find the information needed, find learning materials, as entertainment, and relieve boredom. Gadgets are always used at all times and are often used at inappropriate times such as in the students' learning process using gadgets without the knowledge of the teacher. Even when they are in the toilet, they also play gadgets. The phenomenon of using gadgets has an impact on the social behavior of Ramadhan Islamic boarding school children in Banuaran Nan XX Village, which makes it easy for students to interact with people through social media. Keywords: Gadget Use, Social Behavior, students.
\end{abstract}

Abstrak: Penelitian ini bertujuan untuk melihat fenomena penggunaan gadget dan dampaknya terhadap perilaku sosial anak pesanten ramadhan di Kelurahan Banuaran Nan XX. Jenis penelitian adalah penelitian kualitatif dengan metode deskriptif. Pemilihan informan dilakukan dengan tekhnik Purposive Sampling. Jenis datanya adalah data primer dan data sekunder yang dikumpulkan melalui observasi, wawancara dan studi dokumentasi.Hasil penelitian menunjukkan bahwa sebagian besar santri menggunakan gadget. Fitur-fitur yang sering dipakai adalah kamera, WA, Game, Mp3, youTube, internet dan media sosial. Fitur-fitur tersebut digunakan untuk mencari informasi yang dibutuhkan, mencari bahan pelajaran, sebagai hiburan, dan menghilangkan rasa bosan. Gadget selalu digunakan setiap saat dan sering digunakan disaat yang tidak tepat seperti dalam proses pembelajaran santri menggunakan gadget tanpa sepengetahuan guru. Bahkan pada saat berada di toilet pun juga bermain gadget. Fenomena penggunaan gadget berdampak terhadap perilaku sosial anak pesantren ramadhan di Kelurahan Banuaran Nan XX yaitu membuat santri mudah berinteraksi dengan orang banyak lewat media sosial.

Kata Kunci: Penggunaan Gadget, Prilaku Sosial, santri

\section{A. Latar Belakang Masalah}

Saat sekarang ini dunia sedang mengalami perkembangan yang sangat pesat dalam berbagai bidang dan aspek kehidupan, termasuk perkembangan teknologi informasi dan komunikasi seperti gadget. Dimasa pandemi covid-19 dengan mudahnya komunikasi telah dapat dilakukan dengan belajar jarak jauh. Dahulu komunikasi dilakukan dengan menulis surat dan membutuhkan waktu cukup lama. Namun sekarang alat komunikasi semakin canggih sehingga tidak membutuhkan waktu yang lama yakni dengan mempergunakan Handphone, yang semakin berkembang dan melahirkan yang namanya Gadget. Gadget memang salah satu alat 
yang mampu mempercepat menyelesaikan segala sesuatu yang dibutuhkan. Sehingga dunia ini penuh dengan peralatan gadget yang menjadi kebutuhan utama dunia informasi komunikasi dan teknologi terbaru saat ini (Ichsan,2013:21). Sekarang gadget bukanlah benda asing lagi, hampir setiap orang memilikinya. Bahkan gadget sudah menjadi bagian dari hidup seseorang yang tidak terpisahkan.

Kemajuan teknologi informasi dan komunikasi seperti gadget ini berpengaruh pada perubahan aspek kehidupan, termasuk persoalan prilaku sosial santri. Pengaruh gadget telah membuat banyak generasi muda berubahnya prilaku sosial terhadap sesama manusia, lingkungan dan makhluk hidup lainnya. Sebagaimana Buchari Alma, dkk (2010: 209) mengatakan, "Faktor yang mempengaruhi perilaku sosial seseorang adalah karena kemajuan teknologi, seperti internet, sarana hiburan (Game) dan Televisi". Para remaja menjadi lupa waktu karena terpaku dan sibuk menjelajah dunia maya dan bermain game yang terdapat pada gadget.

Tanpa disadari para remaja lupa dan tidak menghiraukan lingkungan masyarakat sekitar, sehingga rasa peduli terhadap lingkungan sekitar kalah oleh sikap individualisme yang terbentuk dari kegiatan tersebut. Pada dasarnya manusia diciptakan sebagai mahluk sosial yang artinya tidak bisa hidup tanpa orang lain. Manusia itu saling membutuhkan satu sama lain. Keadaan sosial tersebut menuntut manusia untuk hidup berdampingan dengan orang lain sehingga tercipta sebuah kondisi masyarakat yang saling ketergantungan. Maka dari ituperlu adanya prilaku sosial yang baik diantara masyarakat satu dengan masyarakat lain, termasuk pada sesama remaja. Perilaku sosial adalah suasana saling ketergantungan yang merupakan keharusan untuk menjamin keberadaan manusia (Rusli Ibrahim, 2001). Sebagai bukti bahwa manusia dalam memenuhi kebutuhan hidup tidak dapat melakukannya sendiri, melainkan memerlukan bantuan dari orang lain. Manusia dituntut mampu bekerja sama, saling menghormati, tidak menggangu hak orang lain, toleran dalam hidup bermasyarakat. Maka diperlukan suatu usaha melalui pendidikan disekolah yang berupa membina, dan menanamkan prilaku sosial pada diri setiap anak. Sebagaimana dikemukakan oleh Dwi Siswoyo, dkk (2008:17) mengartikan pendidikan sebagai suatu kekuatan yang dinamis dalam kehidupan setiap individu, yang mempengaruhi perkembangan fisiknya, daya jiwanya (akal, rasa dan kehendak), sosial dan moralitasnya.

Berdasarkan pengamatan penulis terhadap santri pesantren ramadhan di Kelurahan Banuaran Nan XX pada tahun 1442 M, dengan melihat beberapa santri menyatakan bahwa sebagian besar santri jika dilihat dari sikap, banyak santri yang tingkah lakunya kurang sopan santun; kurangnya menghormati dan menghargai guru,instruktur dan masyarakat sekitar, kurangnya rasa solidaritas, kebersamaan, dan kesetiakawanan sosial, serta kurangnya rasa kepedulian terhadap sesama dan terhadap lingkungan.Contohnya ada santri yang sibuk bermain gadget tanpa ada perintah dari guru untuk mempergunakan gadget pada saat jam tatap muka berlangsung. Akibatnya santri lainnya terganggu dan proses pembelajaran pun terganggu. Lalu saat berbicara, santri tidak memperhatikan wajah lawan bicaranya karena sibuk dengan gadget. Bahkan saat makan mereka juga tetap bermain gadget. Kemajuan teknologi seperti gadget telah membuat mereka tidak peduli terhadap lingkungan sekitar dan rasa sosial terhadap masyarakat berkurang dan mereka pun menjadi lupa waktu karena sibuk dengan gadget yang mereka miliki.

Terkait dengan hal tersebut upaya yang telah dilakukan panitia pesantren ramadhan tahun $1442 \mathrm{H}$ yang bekerrjasama dengan BKS Keluraahan terhadap dampak penggunaan gadget adalah dengan membuat peraturan untuk tidak menggunakan 
gadget pada saat jam pelajaran berlangsung tanpa ada perintah dari guru bidang keahlian. Jika melanggar akan dikenakan sanksi yang tegas berdasar ketentuan tertentu, seperti akan mengambil gadget tersebut, jika dilakukan lebih dari 3 kali maka pengambilan gadget harus disertai dengan orang tua serta dengan membuat surat perjanjian untuk tidak mengulanginya lagi. Namun hal tersebut tidak memberikan efek jera terhadap santri, gadget sering digunakan disaat yang tidak tepat dan gadget membuat santri sibuk dengan kegiatannya sendiri.

\section{B. Metodologi Penelitian}

Penelitian ini adalah penelitian kualitatif dengan pendekatan deskriptif, guna untuk mendeskripsikan dampak penggunaan gadget terhadap prilaku sosial santri pesantren ramadhan di Kelurahan Banuaran Nan XX. Informan penelitian ini memakai teknik purposive sampling. Jenis datanya adalah data primer, yang di tuturkan langsung oleh informan dan data sekunder adalah data pendukung berupa dokumendokumen, arsip yang menyangkut masalah yang diteliti serta foto-foto. Teknik pengumpulan data dengan observasi, wawancara dan studi dokumentasi. Setelah data terkumpul, diuji keabsahan datanya dengan menggunakan teknik triangulasi sumber data. Lalu diolah dengan teknik analisis data yang digunakan yaitu, pengumpulan data, klasifikasi data, reduksi data, penyajian data, interpretasi data, dan menarik kesimpulan.

\section{Hasil dan Pembahasan}

\section{Fenomena Penggunaan Gadget oleh Santri Pesantren Ramadhan di Kelurahan Banuaran Nan XX.}

Berdasarkan kenyataan yang penulis temui di lapangan, bahwa fenomena penggunaan gadget oleh santri pesantren ramadhan di Kelurahan Banuaran Nan XX adalah santri menggunakan gadget dalam proses pembelajaran yaitu mencari pelajaran. Namun ada beberapa santri yang memanfaatkan situasi tersebut untuk chatingan dimedia sosial dan bermain game. Ada juga santri yang minta izin keluar tetapi digunakan untuk bermain gadget. Banyak santri setiap kegiatan yang dilakukannya diiringi dengan bermain gadget, dan dimana saja berada santri menyempatkan diri untuk melihat gadgetnya. Fenomena penggunaan gadget oleh santri dilihat dari fiturfitur yang sering digunakan santri. Lalu tujuan santri menggunakan fitur-fitur yang terdapat pada gadget tersebut. Setelah itu, tingkat keseringannya (frekuensi) dalam menggunakan gadget dan waktu penggunaan gadget.

Pertama, fitur-fitur yang sering dipakai santri dalam penggunaan gadget. Gadget merupakan salah satu teknologi yang memiliki unsur kebaruan yang mengikuti perkembangan zaman. Apa pun dapat dilihat dan didapatkan melalui gadget karena kecanggihan fitur-fitur yang terdapat pada gadget. Fitur-fitur tersebut ialah internet, YouTube, FB, Twitter, dan Game. Selain itu juga ada kamera, Video Call, telepon, email, sms, bluetooth, Wifi, game dan Mp3.

Kedua, tujuan santri menggunakan gadget. Santri menggunakan fitur-fitur yang terdapat pada gadget tersebut dengan tujuan adalah untuk berkomunikasi dengan orang banyak. Lalu mencari dan mengkonsultasikan pelajaran yang tidak dimengerti. Pelajaran yang tidak diketahui santri dapat dicari dengan menggunakan internet yang terdapat pada gadget. Kemudian dalam mengkonsultasikan pelajaran yang tidak dimengerti, santri menggunakan media sosial untuk membahas pelajaran tersebut dengan temannya. Namun disamping itu sebagian besar santri juga menggunakan gadget untuk hiburan dan menghilangkan rasa bosan. 
Ketiga, Frekuensi (tingkat keseringan) penggunaan gadget. Tingkat keseringan santri menggunakan gadgetnya adalah diperkirakan antara 30 sampai 70 kali menggunakan gadget dalam 1 hari. Penggunaan gadget oleh santri tersebut selalu digunakan setiap saat dan dimana saja berada. Setiap kegiatan yang dilakukan selalu diiringi dengan sambil bermain gadget. Bagi santri gadget sudah menjadi bagian dari hidupnya.

Keempat, waktu dalam penggunaan gadget. Berkaitan dengan hal di atas penggunaan gadget oleh santri ini sering digunakan disaat yang tidak tepat, seperti pada saat berbicara sambil bermain gadget. Sehingga wajah lawan bicaranya tidak terperhatikan. Lalu saat duduk-duduk baik sendiri maupun berkelompok-kelompok, saat berjalan, kemudian pada saat makan, bahkan saat berada di toilet juga bermain gadget. Selanjutnya pada saat dalam perjalanan menuju ke sekolah dan ke Masjid, sebelum pembelajaran dimulai, saat proses pembelajaran berlangsung baik dengan arahan guru maupun tanpa sepengetahuan guru santri bermain gadget. Kemudian saat pulang pesantren ramadhan santri juga bermain gadget. Dalam hal ini dapat disimpulkan lebih kurang $70 \%$ menghabiskan waktunya bermain gadget, yang mana dalam penggunaan gadget oleh santri tersebut sering digunakan disaat yang tidak memungkinkan dan dapat dikatakan penggunaan gadget oleh santri pesantren ramadhan di Kelurahan Banuaran Nan XX kurang terkontrol.

Berdasarkan hal di atas sesuai dengan penggunaan gadget yang dikemukakan oleh WingWinarno (2009:20-21) dan Tara Lioni (2011) dalam penelitiannya berjudul "Pengaruh Penggunaan Gadget Pada Peserta Didik Terhadap Interaksi Sosial" bahwa gadget selain menjadi telepon, juga mendukung banyak layanan tambahan, dan aksesoris, seperti teks pesan, e-mail, akses internet, game, blutooth, kamera, MMS messaging, player radio, MP3 dan GPS, adanya media-media sosial, youTube dan sebagainya. Sehingga dengan banyaknya layanan tambahan tersebut gadget dapat dijadikan sebagai hiburan serta berbagai informasi dapat dengan mudah didapatkan.

\section{Dampak Penggunaan Gadget terhadap Prilaku Sosial Santri Pesantren Ramadhan di Kelurahan Banuaran Nan XX.}

Berdasarkan kenyataan yang penulis temui di lapangan, penggunaan gadget berdampak terhadap prilaku sosial santri. Adapun dampak penggunaan gadget terhadap prilaku sosial santri tersebut adalah : Memudahkan untuk berinteraksi dengan orang banyak lewat media sosial, seperti adanya musibah yang menimpa guru, orang tua santri atau pun santri itu sendiri. Maka dengan gadget dapat menyampaikan berita tersebut kepada banyak orang dengan sekaligus, mudah dan cepat, melalui grup yang dibuat pada media sosial, seperti grup FB atau pun grup WA. Sehingga pihak panitia pesantren dan santri lainnya dapat menjenguk orang yang bersangkutan. Kemudian gadget membuat santri kurangnya berinteraksi dengan tatap muka. yang mana santri hanya mengandalkan gadgetnya, dan lebih memilih berinteraksi melalui gadget dibandingkan dengan berhadapan langsung (tatap muka). Hal ini dapat dilihat dari banyaknya santri dalam mengkonsultasikan, atau pun menanyakan pelajaran yang tidak dimengerti kepada temannya hanya melalui gadget. Mereka malas untuk berkunjung ke rumah temannya dan menanyakannya secara langsung. Karena menurut mereka itu membutuhkan waktu yang lama.

Selain dari itu berbagai macam aplikasi yang terdapat pada gadget membuat santri lebih mementingkan diri sendiri, orang disekitar menjadi terabaikan. Santri tidak peduli terhadap orang lain dan lingkungan sekitarnya, serta kurangnya sikap saling menghargai antar sesama manusia. Seperti dapat dilihat pada saat berbicara santri tidak 
memperhatikan wajah lawan bicaranya, santri yang menggunakan gadget dalam proses pembelajaran tanpa sepengetahuan guru sehingga konsentrasi santri lainnya menjadi terganggu. Hal ini sesuai dengan dampak penggunaan gadget yang disampaikan oleh Doni Harfiyanto, dkk (2015) dalam artikel yang berjudul "Pola Interaksi Sosial Santri Pengguna Gadget di SMA N 1 Semarang” yang mengatakan bahwa penggunaan gadget dapat berdampak positif dan negatif terhadap prilaku sosial santri, yaitu memudahkan berinteraksi dengan orang banyak lewat media sosial, gadget membuat santri lebih mementingkan diri sendiri dan membuat santri tidak peduli terhadap lingkungan sekitar.

Disamping itu selain dampak gadget yang disampaikan menurut teori di atas, penulis menemukan dampak lain yang berkaitan dengan dampak penggunaan gadget terhadap prilaku sosial santri pesantren ramadhan di Kelurahan Banuaran Nan XX, khususnya Kelas IV SD sampai dengan kelas IX SMP. Penulis menemukan bahwa gadget membuat santri kurang berinteraksi dengan tatap muka dan kurangnya sikap saling menghargai terhadap sesama santri, terhadap guru, maupun masyarakat sekitar.

\section{Penutup}

Berdasarkan temuan penelitian yang penulis lakukan di tempat pelaksanaan pesantren ramadhan khususnya di Kelurahan Banuaran Nan XX tentang dampak penggunaan gadget terhadap prilaku sosial santri dapat disimpulkan: Fenomena penggunaan gadget oleh santri pesantren ramadhan tersebut dilihat dari fitur-fitur yang sering digunakannya adalah mereka menggunakan semua fitur-fitur yang terdapat pada gadget terutama seperti media-media sosial, internet, youTube, game, Mp3, video call dan kamera. Dilihat dari tingkat keseringannya dalam menggunakan gadget (Frekuensi): penggunaan gadget selalu digunakan setiap saat, diperkirakan antara 30 sampai 70 kali dalam 1 hari. Kemudian waktu penggunaan gadget tersebut sering digunakan disaat yang tidak tepat dan dapat diperkirakan lebih kurang $70 \%$ menghabiskan waktu untuk bermain gadget. Berdasarkan fenomena penggunaan gadget tersebut maka dapat menimbulkan dampak terhadap prilaku sosial santri pesantren ramadhan di Kelurahan Banuaran Nan XX. Dampak yang ditimbulkan adalah : Memudahkan untuk berinteraksi dengan orang banyak lewat media sosial. Lalu gadget membuat santri kurang berinteraksi dengan tatap muka. Kemudian berbagai macam aplikasi yang terdapat pada gadget membuat santri lebih mementingkan diri sendiri, orang disekitar menjadi terabaikan. Dilihat dari fenomena penggunaan gadget oleh santri serta dampaknya tersebut, maka dapat dikatakan bahwa segala sesuatu yang dilakukan diiringi dengan sambil bermain gadget dan penggunaan disaat yang tidak tepat, akan cenderung mengakibatkan berubahnya prilaku sosial seseorang, terutama santri pesantren ramadhan.

\section{Daftar Pustaka}

Buchari Alma, dkk. (2010). Pembelajaran Studi Sosial. Bandung: Alfabeta Rusli, Ibrahim, 2001, Psikologi Perkembangan, Bandung : PT Rosda Karya Remaja. William/Sawyer, 2007, Using Information Technology terjemahan Indonesia, penerbit Andi.

Winarno, Wing. 2009. Panduan Penggunaan Gadget. Jakarta: Rineka Cipta.

Harfiyanto, Doni, dkk. 2015. Pola Interaksi Sosial Santri Pengguna Gadget Di Sma N

1 Semarang. http://journal.unnes.ac.id/sju/index.php/jess. Diakses tanggal 20 Mei 2021.

Buku Panduan Pesantren Ramadhan tahun 1442 H/2021 M. 